\title{
Assessment of primary school students' level of understanding the concepts of 2 nd grade life sciences course based on different variables
}

\author{
Gülşen Altıntaş ${ }^{2}$, Behsat Savaş ${ }^{1}$, and Margrit Yeşiltepe ${ }^{3 a}$, \\ ${ }^{1}$ Primary School Teaching Department, Mehmet Akif Ersoy University, Burdur, Turkey \\ ${ }^{2}$ Education Programs and Teaching Department, Celal Bayar University, Demirci/Manisa, Turkey \\ ${ }^{3}$ Yildiz Technical University Education Programs and Teaching Department Non-Thesis Master's \\ Program, Besiktas, Istanbul, Turkey
}

\begin{abstract}
The course of Life Sciences is one of the pivot courses taught in the first three years of primary school. Ensuring children get to know their environment and gain correct information related to their problems by making them investigate their natural and socio-cultural environment as well as providing them with necessary information, skills and behaviors for environmental adaptation are among the main purposes of Life Sciences course. The concepts to be instilled in students in line with these purposes are important. Since concepts are mostly intellectual and non-physical, they can only exist tangibly through examples. This study aims to assess Primary School Students' Level of Understanding the Concepts of 2nd Grade Life Sciences Course Based on Different Variables. 17 concepts included in the 2nd Grade Life Sciences course within the subject of School Excitement were addressed within the study, and students were requested to define and exemplify these concepts. A total of 102 students from five different primary schools of upper-middle and lower socioeconomic classes located in Manisa and Istanbul were included in the study in line with the intentional maximum diversity sample selection. The answers given by students for each concept were categorized and analyzed in terms of liking or disliking home, school, technology and the course of Life Sciences.
\end{abstract}

Keywords: Life sciences, concept, manner

\section{Introduction}

Education is an indispensable factor for developing and producing societies. Educated individuals are the ones "who make critic and creative inventions and discoveries, and desire to commence social change." Preparing this change in individuals is one of the

\footnotetext{
a Corresponding author: margrithe@hotmail.com
} 
creative functions of education. Satisfying the needs of society also means satisfying the needs of individual. Being educated and implementing right decisions may not guarantee happiness, virtue and economical success. However; it is certain that education provides people with better opportunities in all these subjects. Educated individuals are expected to question the information and expressions they learn, accept and encounter, make logical deductions from them, and associate them with daily life. In education, the existence of critical and creative thinking as well as the acquisition of these by individual affect not only the daily life, but also the academic success of that individual, [5], [6].

Children develop curiosity for anything surrounding them from the very moment they are born. The course of Life Sciences may be used as an important opportunity to direct and develop their feeling of curiosity as they grow. Güngördü, [3] states that the development of child is holistic according to Gestalt psychology, and argues that because child sees things and events in their entirety and tends to learn them as a whole, the information and skills to be provided to child should be addressed as a whole rather than in different courses, a phenomenon that may be possible through the course of Life Sciences. Some of the behaviors expected from a student after this course are as follow: being able to solve the problems he/she encounters in his/her life, being a good producer and consumer, being able to understand basic information and phenomena, being able to think multi-dimensional, and being able to use scientific methods. Ensuring that a child/student gets to know his/her environment, providing $\mathrm{him} / \mathrm{her}$ with correct and concrete information regarding environmental problems as well as teaching him/her necessary skills and behaviors for environmental adaptation by making him/her examine his/her environment are the some of the main purposes of the Life Sciences course, [8].

There are some concepts that children encounter during the course of environmental adaptation. While teaching concepts, repetitions without undue delay are important in order to ensure that the features in question pass from short-term memory to long-term memory. The feedback process to be carried out through key questions and concepts as well as making students identify, describe, classify, analyze, and synthesize equip them with intellectual thinking skill. Traditional concept learning is made up of (a) Presentation of the concept, (b) Definition, (c) Presentation of identifying and distinguishing features of the concept, and (d) presentation of the examples related and unrelated with the concept (YÖK/World Bank, 1997). When more than one concept is encountered, dividing the ones related with each other into groups and classifying them increase their learnability.

In this study, primary school students' level of understanding the concepts of 2 nd grade life sciences course was assessed based on different variables. 17 concepts included in the 2nd Grade Life Sciences course within the subject of School Excitement were addressed within the study, and students were requested to define and exemplify these concepts.

\section{Method}

17 concepts included in the 2nd Grade Life Sciences course within the subject of School Excitement were addressed within the study, and data were collected as through the definition and exemplification of these concepts by students. Students included in the study were coded as S1, S2 and S3, and the data collected were subjected to qualitative analysis.

Within the study, the data collected were analyzed with the method of content analysis. The main purpose of the content analysis is to reach the concepts and relations which can explain the data collected as a result of the study. Descriptive analysis techniques were also used during the analysis process. The purpose of descriptive analysis is to present the information acquired as a result of the study in an ordered and interpreted way. The data acquired with this purpose are described systematically and in an open way at first. Then, such descriptions are explained and interpreted, the cause-effect relation between them is 
analyzed and a number of results are reached. Furthermore, in scientific analysis, direct quotations are generally used in order to reflect individuals' opinions. The basic process carried out in order to achieve this goal to gather similar data within the scope of specific concepts and subjects, and organize and interpret them so that they can be understood by readers. 17 concepts within the subject of School Excitement included in the course of Life Sciences for 2nd Grade Students were analyzed in four steps, which are respectively Coding, Classification, Validity and Confidence, and Computerization of the data.

\subsection{Coding step}

The concepts defined and exemplified by students were ranked in alphabetical order, and coded according to the way they were expressed by each student.

\subsection{Classification step}

Content analysis was performed in this step. The concepts defined and exemplified by students were reviewed, and sentences were classified as missing, semi-correct and correct. Students who did not provide definitions or examples for concepts were excluded from the study.

\subsection{The step of validity and confidence}

In this step, opinions of a Social Sciences Teacher, a Primary School Teacher and an Educational Sciences Expert were asked in order to determine whether the concepts defined and exemplified by students represented the codes. The experts were given a list including the definitions and examples provided by students and a list of categories. The confidence of the study was calculated using the confidence formula (Number of Agreement/[Consensus + Dissidence]) developed by Miles and Huberman. These are the concepts of Informed Consumer, Courage, Syllabus, Religious Holiday, Feeling, Visual Material, Communication, Reference Book, Kindness, Sharing, Project, Health, Respect, Shape, Transportation Vehicles, Body and Help, which were categorized by experts as broad concepts. According to this, an agreement was reached with the experts on the definitions and examples regarding the 17 concepts. Confidence was found as 0.91 as a result of the calculation performed. Where the accord between the assessments performed by experts and investigators was $\% 90$ and more, it is assumed that the desired confidence is ensured.

In a qualitative research, detailed reporting of the collected data as well as the statements of investigators are important measures regarding validity; furthermore, including the opinions of respondents directly and citing from them as well as explaining the results based on these are also important for validity. With this purpose, the definitions and examples given by students were cited in the study.

\subsection{Computerization of the data}

The concepts and examples formed as well as the related data were computerized in this step. After this process, the number of students representing each concept and example (f) and their percentage $(\%)$ were calculated. 


\subsection{Study group}

A total of 102 students studying at five different primary schools of upper-middle and lower socio-economic classes located in Manisa and Istanbul in 2014-2015 academic year were included in the study. A student was excluded as he/she did not provide concept definitions and examples. Personal characteristics of the students are given below.

Table 1. Distribution of the primary school students participating in the study by gender

\begin{tabular}{ccc}
\hline Gender & N & Number of Students \\
& 49 & 48.5 \\
Female & 52 & 51.5 \\
Male & 101 & 100 \\
Total & & \\
\hline
\end{tabular}

According to Table 1, 48.5\% of the students were female while 51.5 of them were male.

\section{Results}

Table 2. Distribution of the primary school students participating in the study by income status

\begin{tabular}{ccc}
\hline Income Status & \multicolumn{2}{c}{ Number of Students } \\
& $\mathrm{f}$ & 29.7 \\
\hline Low Income & 30 & 43.6 \\
Middle Income & 44 & 26.7 \\
High Income & 27 & 100 \\
\hline Total & 101 & 00 \\
\hline
\end{tabular}

According to Table 2, 29.7\% of the students participating in the study had low income, $43.6 \%$ of them had middle income, and $26.7 \%$ of them high income status.

Table 3. Distribution of the primary school students participating in the study by whether they have their own separate rooms at home

\begin{tabular}{ccc}
\hline Separate Room & Number of Students & $\%$ \\
\hline Yes & f & 36.6 \\
No & 37 & 63.4 \\
Total & 101 & 100 \\
\hline
\end{tabular}

According to Table 3, 36.5\% of the students have separate rooms while $63.4 \%$ of them do not.

Table 4. Distribution of the primary school students participating in the study by their use of computer

\begin{tabular}{ccc}
\hline Use of Computer & N & Number of Students \\
& 63 & 62.4 \\
Yes & 38 & 37.6 \\
No & 101 & 100 \\
Total & & \\
\hline
\end{tabular}

According to Table $4,62.4 \%$ of the students participating in the study use computer while $37.6 \%$ of them do not.

Table 5. Distribution of the primary school students participating in the study by whether they like or dislike school

\begin{tabular}{ccc}
\hline School & Number of Students & $\%$ \\
\hline Like & f & 97 \\
Dislike & 3 & 3 \\
Total & 101 & 100 \\
\hline
\end{tabular}


According to Table 5, 97\% of the students participating in the study like school while $3 \%$ of them do not.

Table 6. Distribution of the primary school students participating in the study by whether they like or dislike the course of life sciences

\begin{tabular}{ccc}
\hline Course of Life Sciences & Number of Students & $\%$ \\
\hline Like & f & 89.1 \\
Dislike & 11 & 10.9 \\
Total & 101 & 100 \\
\hline
\end{tabular}

According to Table $6,89.1 \%$ of the students participating in the study like school while $10.9 \%$ of them do not.

Table 7. Distribution of the concepts within the subject of school excitement included in the 2nd grade life sciences course by identification classification

\begin{tabular}{ccc}
\hline Concept Classification & $\mathrm{f}$ & $\%$ \\
\hline Blank & 468 & 30.47 \\
Missing & 125 & 8.14 \\
Semi-Correct & 781 & 50.85 \\
Correct & 162 & 10.54
\end{tabular}

According to Table 7, while the students participating in the study defined the concepts within the subject of School Excitement included in the 2nd grade Life Sciences course as semi-correct at the maximum rate of $50.85 \%$, they defined them as correct at the minimum rate of $10.54 \%$.

Table 8. Distribution of the concepts within the subject of school excitement included in the 2nd grade life sciences course by example classification

\begin{tabular}{ccc}
\hline Example Classification & $\mathrm{f}$ & $\%$ \\
\hline Blank & 878 & 57.61 \\
Missing & 123 & 8.07 \\
Semi-Correct & 262 & 17.19 \\
Correct & 261 & 17.13 \\
\hline
\end{tabular}

According to Table 8, while the students participating in the study did not exemplify the concepts within the subject of School Excitement included in the 2nd grade Life Sciences course and left them blank at the maximum rate of $50.85 \%$, they provided missing examples at the minimum rate of $10.54 \%$.

When Table 9 is viewed, it is seen that while the concept left blank the most is "Project" among the Concepts within the subject of School Excitement Included in the 2nd Grade Life Sciences Course with a rate of $60.4 \%$, the one left blank the least is "Help" with a rate of $12.9 \%$. While the concept left missing the most was "Reference Book" with a rate of $4 \%$, the one left missing the least was "Visual Material" with $14.9 \%$. While the concept defined semi-correct the most was "Help" with a rate of $63.4 \%$, the one defined the least was "Project" with a rate of $21.8 \%$. While the concept defined correctly the most was "Health" with a rate of $15.8 \%$, the one defined the least was "Courage" with a rate of $4 \%$. When the table is viewed from a general perspective, it is seen that concepts were defined semicorrectly in addition to being left blank. The concept of "Project" was included in both options. It is seen that when required to define concepts, students mostly preferred to use them in sentences. 
Table 9. Distribution of the concepts within the subject of school excitement included in the 2nd grade life sciences course by identification status

\begin{tabular}{lcccccccc}
\hline \multicolumn{1}{c}{ Concept } & \multicolumn{2}{c}{ Blank } & \multicolumn{2}{c}{ Missing } & \multicolumn{2}{c}{ Semi-Correct } & \multicolumn{2}{c}{ Correct } \\
\hline & $\mathrm{f}$ & $\%$ & $\mathrm{f}$ & $\%$ & $\mathrm{f}$ & $\%$ & $\mathrm{f}$ & $\%$ \\
Informed Consumer & 29 & 28.7 & 8 & 7.9 & 55 & 54.5 & 9 & 9.9 \\
Courage & 44 & 43.6 & 12 & 11.9 & 41 & 40.6 & 4 & 4 \\
Syllabus & 22 & 21.8 & 8 & 7.9 & 61 & 60.4 & 10 & 9.9 \\
Religious Holiday & 29 & 28.7 & 7 & 6.9 & 56 & 55.4 & 9 & 8.9 \\
Feeling & 42 & 41.6 & 7 & 6.9 & 45 & 44.6 & 7 & 6.9 \\
Visual Material & 46 & 45.5 & 15 & 14.9 & 32 & 31.7 & 8 & 7.9 \\
Communication & 43 & 42.6 & 7 & 6.9 & 42 & 41.6 & 9 & 8.9 \\
Reference Book & 30 & 29.7 & 4 & 4 & 61 & 60.4 & 6 & 5.9 \\
Kindness & 45 & 44.6 & 9 & 8.9 & 38 & 37.6 & 9 & 8.9 \\
Sharing & 41 & 40.6 & 7 & 6.9 & 40 & 39.6 & 12 & 11.9 \\
Project & 61 & 60.4 & 5 & 5 & 22 & 21.8 & 13 & 12.9 \\
Health & 28 & 27.7 & 12 & 11.9 & 45 & 44.6 & 16 & 15.8 \\
Respect & 26 & 25.7 & 8 & 7.9 & 59 & 58.4 & 8 & 7.9 \\
Shape & 33 & 32.7 & 7 & 6.9 & 56 & 55.4 & 5 & 5 \\
Transportation & 26 & 25.7 & 6 & 5.9 & 57 & 56.4 & 12 & 11.9 \\
Vehicles & & & & & & & & 9.9 \\
Body & 30 & 29.7 & 9 & 8.9 & 52 & 51.5 & 10 & 10 \\
Help & 13 & 12.9 & 9 & 8.9 & 64 & 63.4 & 15 & 14.9 \\
\hline
\end{tabular}

Table 10. Distribution of the Concepts within the subject of School Excitement Included in the 2nd Grade Life Sciences Course by the Status of the Examples Given for the Concepts

\begin{tabular}{|c|c|c|c|c|c|c|c|c|}
\hline \multirow[t]{2}{*}{ Concept } & \multicolumn{2}{|c|}{ Blank } & \multicolumn{2}{|c|}{ Missing } & \multicolumn{2}{|c|}{ Semi-Correct } & \multicolumn{2}{|c|}{ Correct } \\
\hline & $\mathrm{f}$ & $\%$ & $f$ & $\%$ & $\mathrm{f}$ & $\%$ & $\mathrm{f}$ & $\%$ \\
\hline $\begin{array}{l}\text { Informed } \\
\text { Consumer }\end{array}$ & 60 & 59.4 & 9 & 8.9 & 15 & 14.9 & 17 & 16.8 \\
\hline Courage & 63 & 62.4 & 9 & 8.9 & 17 & 16.8 & 12 & 11.9 \\
\hline Syllabus & 50 & 49.5 & 4 & 4 & 26 & 25.7 & 21 & 20.8 \\
\hline $\begin{array}{l}\text { Religious } \\
\text { Holiday }\end{array}$ & 55 & 54.5 & 9 & 8.9 & 15 & 14.9 & 21 & 20.8 \\
\hline Feeling & 59 & 58.4 & 10 & 9.9 & 18 & 17.8 & 14 & 13.9 \\
\hline $\begin{array}{l}\text { Visual } \\
\text { Material }\end{array}$ & 62 & 61.4 & 10 & 9.9 & 15 & 14.9 & 14 & 13.9 \\
\hline $\begin{array}{l}\text { Communicat } \\
\text { ion }\end{array}$ & 64 & 63.4 & 6 & 5.9 & 11 & 10.9 & 20 & 19.8 \\
\hline $\begin{array}{l}\text { Reference } \\
\text { Book }\end{array}$ & 61 & 60.4 & 10 & 9.9 & 7 & 6.9 & 23 & 22.8 \\
\hline Kindness & 60 & 59.4 & 6 & 5.9 & 16 & 15.8 & 19 & 18.8 \\
\hline Sharing & 62 & 61.4 & 8 & 7.9 & 19 & 18.8 & 12 & 11.9 \\
\hline Project & 43 & 42.6 & 10 & 9.9 & 40 & 39.6 & 8 & 7.9 \\
\hline Health & 62 & 61.4 & 8 & 7.9 & 15 & 14.9 & 16 & 15.8 \\
\hline Respect & 64 & 63.4 & 5 & 5 & 18 & 17.8 & 14 & 13.9 \\
\hline Shape & 64 & 63.4 & 2 & 2 & 14 & 13.9 & 21 & 20.8 \\
\hline $\begin{array}{l}\text { Transportati } \\
\text { on Vehicles }\end{array}$ & 49 & 48.5 & 7 & 6.9 & 16 & 15.8 & 29 & 28.7 \\
\hline Body & 60 & 59.4 & 5 & 5 & 25 & 24.8 & 11 & 10.9 \\
\hline Help & 59 & 58.4 & 6 & 5.9 & 16 & 15.8 & 20 & 19.8 \\
\hline
\end{tabular}

While, according to Table 10, the concepts left blank the most in terms of exemplifying were "Communication," "Respect" and "Shape" among the Concepts within the subject of School Excitement Included in the 2nd Grade Life Sciences Course with a rate of $63.4 \%$, the one left blank the least was "Project" with a rate of $42.6 \%$.

The ones left missing the most in terms of exemplifying were "Project," "Reference Book," "Visual Material" and "Feeling" with a rate of $9.9 \%$, the one left missing the least was "Shape" with a rate of $2 \%$. 
While the concept defined semi-correctly the most in terms of exemplifying was "Project" with a rate of $39.6 \%$, the one defined the least was "Reference Book" with a rate of $6.9 \%$.

While the concept defined correctly the most in terms of exemplifying was "Transportation Vehicles" with a rate of $28.7 \%$, the one defined the least was "Project" with a rate of $7.9 \%$.

When the table is viewed from a general perspective, there is the concept "Project" in all classifications.

It is seen that when required to define concepts, students mostly preferred to use them in sentences.

As a result of the analysis carried out based on the criteria of liking/disliking home, school, technology and the course of Life Sciences after the categorization of the answers and examples given by students for the concepts, it was seen that male students $(57.3 \%)$ answered more correctly than female students (42.7\%). Both groups answered correctly at a close rates in terms of tangible and concrete concepts (Female Students $=51 \%$, Male Students $=49 \%)$. Those who had a separate room at home $(75.5 \%)$ gave more correct answers and examples compared to those who did not have a separate room at home (24.5\%). Those who liked the course of Life Sciences (97\%) gave more correct answers and examples compared to those who disliked it $(3 \%)$. All of those who liked school (100\%) gave correct answers and examples. Those who used computer (57\%) made more correct definitions and gave more correct examples compared to those who did not use computer.

\section{Conclusion and discussion}

In the study, students were required to define and exemplify 17 concepts within the subject of School Excitement included in the 2nd grade Life Sciences Course, and the concepts were then assessed based on different variables. All of those who did not have their own rooms at home as well as those who liked school and the course of Life Sciences in addition to those who used computer made more correct definitions and gave more correct answers. According to Coştu, Ayas and Ünal, [2] lack of knowledge as well as the lack of actions aimed at concretion and previous incorrect experiences and thoughts caused misconception. Also in our study, the fact that there are many cases where concepts were not defined or exemplified but left blank indicates the students' lack of knowledge as well as the lack of concretion actions, while missing and incorrect definitions and exemplifications indicate that the concepts are not associated with daily life skills.

When the 2nd Grade Life Sciences curriculum is assessed, it is seen that there are thirty different topics in the subject of "School Excitement." Seventeen concepts within the subject take place in 11 of these topics, while they do not in 15 of the topics. While twelve concepts (Health, transportation vehicles, help, sharing, project, communication, courage, religious holiday, informed consumer, reference book and syllabus) take place in the last topic of the subject titled "What Have We Learned," the other six concepts (shape, visual material, kindness, body, feeling and respect) are not included. Intense content indicates that the behaviors, skills and values to be gained by students are not formed in the quality desired.

In concept and term teaching, interaction between examples and exemplary materials should be ensured, considering the development level of students. The content of the Life Sciences course, which prepares the basis for life-time learning, should support daily life skills more, while including less content and more activities. The level of students' 
understanding, defining and exemplifying a concept may be assessed, taking into consideration concept teaching and activity associations.

\section{References}

1. Altunçekiç, A., Yaratıcı ve Eleştirel Düşünmeye Dayalı Laboratuar Yönteminin Öğretmen Adaylarının Akademik Başarı, Problem Çözme ve Laboratuar Tutum Düzeylerine Etkisi [Effect of Laboratory Management Based on Creative and Critical Thinking on Teacher Candidates' Academic Success, Problem Solving and Laboratory Behavior Levels], XIII. National Education Sciences Congress, 6-9 July, İnönü University, Faculty of Education, Malatya, (2004).

2. Coştu, B., Karataş, F.Ö. \& Ayas, A., Use of studying leaves in concept teaching. Pamukkale University Faculty of Education Journal, 2 (14), 33-48, (2003).

3. Güngördü, E., Life Sciences and Social Sciences Teaching in Primary Education. Ankara: Nobel Yayın Dağıtım, (2001).

4. Gürdal, A., Importance of Physical Sciences in Primary Education. Hacettepe University, Faculty of Education Journal, 8, 185-188, (1992).

5. Güven, M. \& Kürüm, D., Öğrenme Stilleri ve Eleştirel Düşünme Arasındaki İlişkiye Genel Bir Bakış (An Overview on the Relation Between Learning Styles and Critical Thinking, Sosyal Bilimler Dergisi (Social Sciences Journal), 6(1) 75-89, (2006).

6. Koray, Ö., Yaman, S. \& Altunçekiç, A., Yaratıcı ve Eleştirel Düşünmeye Dayalı Laboratuar Yönteminin Öğretmen Adaylarının Akademik Başarı, Problem Çözme ve Laboratuar Tutum Düzeylerine Etkisi [Effect of Laboratory Management Based on Creative and Critical Thinking on Teacher Candidates' Academic Success, Problem Solving and Laboratory Behavior Levels], XIII. National Education Sciences Congress, 6-9 July, İnönü University, Faculty of Education, Malatya, (2004).

7. Novak, J., Human constructivism: A unification of psychological and epistemological phenomena in meaning making, International Journal of Personal Construct Psychology, 6, 167-193, (1993).

8. Öztürk, C. \& Dilek, D. (2003). Life Sciences and Social Sciences Teaching. Ankara: Pegem A Yayıncılık. 